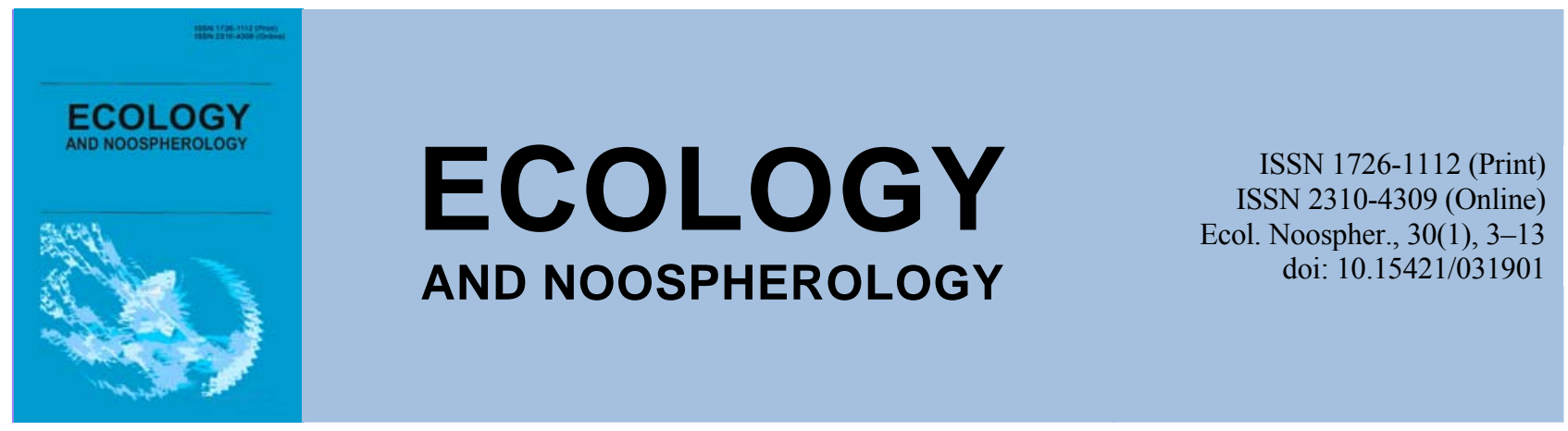

\title{
Transformation of the community of nesting birds in the process of reorganization of the forest ecosystem into a park
}

\author{
V. A. Gaychenko*, T. V. Shupova** \\ *National University of life and environmental sciences of Ukraine, Kyiv, Ukraine \\ **Institute for Evolutionary Ecology of the NAS of Ukraine, Kyiv, Ukraine
}

Article info

Received 03.03.2019

Received in revised form 11.03.2019

Accepted 20.03.2019

National University of life and environmental sciences of

Ukraine, Heroiv Oborony str., 15, Kyiv, 03041, Ukraine.

Institute for Evolutionary Ecology of the NAS of Ukraine, Lebedeva str., 37, Kyiv, 03143, Ukraine.

Tel.: +38-095-421-03-42

E-mail:tv.raksha@gmail.com
Gaychenko, V. A., Shupova, T. V. (2019). Transformation of the community of nesting birds in the process of reorganization of the forest ecosystem into a park. Ecology and Noospherology, 30(1), 3-13. doi:10.15421/031901

Changes in nesting conditions cause a change in the number of individual species, ecological groups, and, consequently, the structure of the bird community. The purpose of the study is to analyze the possibilities and directions - the transformations of the communitys of nesting birds in the process of reorganization of the forest ecosystem into a park. The material was collected in the territory of one of the forest parks in the Kiev city. Forest is an mixed based on Quercus robur L., Carpinus betulus L., Acer platanoides L., Tilia cordata L., Fraxinus excelsior L. There are individual trees Pinus Syvestris L. The territory of the forest park have different degrees transformed, and includes anthropogenic landscapes and forests plots that have been preserved almost in their natural state. Studies were conducted in the nesting period (April-June) 2012-2017. For analysis average data were used. The number and distribution of the birds were determined by the method of counting on the transects, in the 3 model plots. There are 71 species of birds of 11 orders. Of these, 63 species are nesting. The number of nested species of communities in model plots does not depend on the gradient of anthropogenic transformation, but a average density of nesting birds decrease: $2.91 \pm 0.66 \rightarrow 2.54 \pm 0.67 \rightarrow 2.10 \pm 0.48$ pairs / $\mathrm{km}$ of the transect. Nesting birds are distributed between 9 faunogenetic complexes. Of these, in each model plot is represented by 8 . Dominated by birds of the European nemoral complex. On the gradient of habitat transformation, a change in the fauna-genetic structure of bird communities in the direction of increasing the proportion of birds of the European nemoral and European forest-steppe complexes, birds of desert-mountain and tropical groups. Boreal and ancient species are superseded. Strengthening the transformation in forest plots, the distribution of birds in community on the ecological groups does change not much. But when the forest ecosystem is replaced by a park ecosystem, the proportion of sclerophiles increases 3-4 times. In all communities is dominated by woody nesters bird. On the gradient of transformation, the number of species of the tree canopies nesters birds (from 21 to 18), ground nesters birds (from 6 to 0 ), species that use many types of nesting stations (from 4 to 1 ) are decreases; the number of bird species that nesting in the buildings increases from 0 to 6 , and the number of alien species from 0 to 4 (Streptopelia decaocto, Dendrocopos syriacus, Phoenicurus ochruros, Serinus serinus). In the park ecosystems, a decrease in the species composition of woodpeckers, does not entail a significant decrease in the species composition and abundance of secondary hollows nesters birds. Birds of the synanthropic subpopulations are nesting in cavities in park buildings. Most of the indices show an equivalent $\alpha$-diversity of all bird communities. The $\beta$-diversity of breeding birds during the transformation of the forest ecosystem into a park is reduced by half. Ranked distribution curves of the abundance of species are indicate abrupt changes in the balance of dominance-diversity in communities when a transformation are in the forest ecosystem. The dominant species pressure high are give in community, its abundance is $2.2-2.7$ times higher than the abundance of the second species by the abundance. In a slightly transformed forest, this indicator is 1.1 times. Ranked curves of relative abundance of species are a more sensitive index of community transformation than data of indices by the dominance and of species distribution. The introduction into the forest ecosystem of even a small number of anthropogenic structures leads to a significant increase in the relative abundance of synanthropic birds. In our study, in to 2 times. On the gradient of the transformation the absolute number of nesting species of the synanthropic birds increases gradually: 30-33-36; the obligate synanthropic species more stronger: $0-2-7$; the index of community synanthropization increases 1.5 times: $0.63-0.72-0.92$.

Keywords: species diversity; faunogenetic structure; ecological structure; community of the nesting birds; synanthropization; gradient of transformation forest-park 


\title{
Трансформація угруповань птахів, що гніздяться в процесі перетворення лісової екосистеми в паркову
}

\author{
В. А. Гайченко*, Т. В. Шупова** \\ *Національний університет біоресурсів і природокористування Украӥни, Київ, Україна \\ **Інститут еволюиійної екологї̈ НАН Украӥни, Київ, Украӥна
}

Зміни умов гніздування викликають зміни чисельності окремих видів, екологічних груп i, отже, структури угруповання птахів. Метою дослідження є аналіз можливостей і напрямків трансформації угрупування птахів, що гніздяться в дубовограбовому лісі, у процесі перетворення лісових екосистем у паркові. Матеріал збирали на території лісопарку, розташованого на околиці м. Києва. Ліс його - змішана діброва на основі Quercus robur L., Carpinus betulus L., Acer platanoides L., Tilia cordata L., Fraxinus excelsior L. С окремі дерева Pinus sylvestris L. Територія лісопарку трансформована в різній мірі і включає антропогенний ландшафт і ділянки лісу, що збереглися практично в природному стані. Дослідження проводили в гніздовий період (квітень - червень) 2012-2017 рр. Чисельність і розподіл птахів визначали методом обліків на маршрутах на 3 модельних ділянках. Для аналізу використовували середні дані чисельності для кожного маршруту за весь період дослідження. Відзначено 71 вид птахів 11 рядів. Кількість видів, що гніздяться, угруповань модельних ділянок не залежить від градієнта антропічної трансформації, а їх середня чисельність знижується: 2,91 $\pm 0,66 \rightarrow 2,54 \pm 0,67 \rightarrow 2,10 \pm$ 0,48 пар/км. Орнітофауна розподілена на 9 ландшафтно-генетичних фауністичних комплексів, з яких на кожній модельній ділянці представлено по 8. Домінують птахи європейського неморального комплексу. За градієнтом трансформації умов проживання встановлено зміну фауно-генетичної структури угруповань птахів у напрямку збільшення часткової кількості птахів європейського неморального, європейського лісостепового, пустельно-гірського і тропічного комплексів за рахунок витіснення інтразональних бореальних і стародавніх видів. При посиленні трансформації в межах лісових ділянок розподіл птахів угруповання за екологічними групами змінюється несуттєво, але при заміні лісової екосистеми на паркову різко (в 3-4 рази) зростає частка склерофілів. У всіх угрупованнях птахів на гніздуванні переважають дендрофіли. За градієнтом трансформації зменшується число видів птахів, що гніздяться відкрито в кронах рослин з 21 до 18; видів, пристосованих до використання декількох типів гніздових стацій - 34 до 1; видів, що облаштовують гнізда на землі - 36 до 0 . Число видів птахів, що гніздяться в нішах будівель, зростає з 0 до 6, а число чужорідних видів - 30 до 4 (Streptopelia decaocto, Dendrocopos syriacus, Phoenicurus ochruros, Serinus serinus). У зв'язку з цим в паркових екосистемах зменшення видового складу дятлів не тягне за собою суттєвого зменшення видового складу і великої кількості вторинних дуплогнізників, оскільки представники синантропних субпопуляцій використовують для гніздування порожнини в будівлях 3 благоустрою парку. Більшість застосовуваних для аналізу о́-різноманітності індексів показує рівноцінну якість всіх угруповань. Показники $\beta$-різноманітності птахів, що гніздяться при трансформації лісової екосистеми в паркову, знижуються вдвічі. Ранжирувані криві розподілу відносної кількості видів в угрупованнях птахів указують на різкі зміни балансу домінуваннярізноманітності в угрупованнях при внесенні трансформації в лісову екосистему і на високий прес в угрупованні одного домінуючого виду, велика кількість якого в 2,2-2,7 разу перевищує велику кількість другого за чисельністю виду спільноти. Порівняльний аналіз розподілу видів за щільністю і за часткової кількості вказує на те, що ранжирувані криві великої кількості видів $\epsilon$ більш чутливим показником трансформації угруповання, ніж дані індексів домінування і рівномірності розподілу видів в угрупованні. Впровадження в лісову екосистему навіть невеликої кількості будівель призводить до істотного збільшення відносної кількості синантропних птахів: на сильнотрансформованій лісовій ділянці вона вдвічі вища, ніж на слабкотрансформованій. За градієнтом трансформації ділянок абсолютне число гніздових синантропних видів птахів збільшується поступово: 30-33-36; облігатних синантропів різкіше: 0-2-7; індекс синантропізації спільнот підвищується в 1,5 разу: $0,63-0,72-0,92$.

Ключові слова: видове різноманіття; фауно-генетична структура; екологічна структура; угруповання птахів, що гніздяться; синантропізація; градієнт трансформації ліс-парк

\section{Введение}

При современном уровне антропического воздействия на природную среду мы наблюдаем существенные изменения условий обитания животных и растений: загрязнение окружающей среды, разрушение грунтового и растительного покрова, его фрагментацию и, как следствие, - трансформацию экосистем. Преобразование ландшафтов, происходящее под влиянием деятельности человека, имеет прямое отношение к исчезновению малочисленных видов животных, которые особенно резко реагируют на сокращение мест обитания (Chaplygina et al., 2016). Часто результатом действия чрезмерного антропического пресса является элиминация из сообществ животных, не адаптировавшихся к соседству человека аборигенных видов и формированию нового сообщества (Shupova, 2017a). Освободившиеся экологические ниши занимают чужеродные виды, уже адаптированные к обитанию в трансформированном ландшафте. Внедрение их в фауну Украины происходит путем заселения в первую очередь урбанизированных биотопов. Эти биотопы представляют собой мозаичный ландшафт и насыщены зданиями, что придает им, как среде обитания, сходство в разных странах Европы (Croki et al., 2009). Увеличение площадей населенных пунктов способствует дальнейшему уничтожению естественных биотопов и вытеснению аборигенных видов. В составе фауны урбанизированных биотопов остаются в основном виды, способные адаптироваться к обитанию в условиях действия фактора беспокойства и изменения ряда экологических и этологических особенностей (Palomino \& Carrascal, 2005; Bulakhov et al., 2008, 2015; Kurosawa, 2009; Pakhomov et al., 2011; Shupova, 2015).

Целью исследования является анализ возможностей и направлений трансформации сообщества гнездящихся птиц дубово-грабового леса при преобразовании лесных экосистем в парковые. При исследовании нарушений функционирования экосистемы птицы являются особо выгодной таксономической группой, так как выполняют в ней разнообразные и важные экологические функции и их легко идентифицировать визуально и акустически (Şekercioğlu, 2006; Etterson et al., 2007, Fischer et al., 2007; Gardner et al., 2008; Whelan et al., 2008). Изменения условий гнездования вызывают изменения численности отдельных видов и экологических групп птиц и, следовательно, структуры сообщества. Для установления 
зависимостей между трансформацией фитоценоза и орнитофауны особенно актуальны исследования именно гнездящихся птиц. Птицы на этой стадии жизненного цикла, когда связь с биотопом тесная, находятся в прямой зависимости от воздействий на экосистему (Camprodon \& Brotons, 2006; Shupova \& Chaplygina, 2016).

\section{Материал и методы исследований}

Площадкой для исследования выбран парк-памятник садово-паркового искусства «Феофания», расположенный на южной окраине г. Киева. Google координаты парка: 50.341832 , 30.489038. Киев расположен на территории 2 природно-географических зон: лесной и лесостепной. Площадь города 836 км²$^{2}$. Для юго-западной и южной части Киева характерны лесостепные смешанные дубравы (Romanenko et al., 2015). ППСПИ «Феофания» имеет площадь 150 га и практически полностью расположен в Обуховско-Васильковском физико-географическом районе Лесостепной области Киевского плато. Территория парка прорезана глубокими балками с задернованными покрытыми лесом склонами и узкими тальвегами, трансформирована в разной степени. Она включает как антропогенный ландшафт, так и участки, сохранившиеся практически в естественном состоянии. В антропогенный ландшафт парка-памятника выделены: садово-парковый городской, антропогенно-аквальный, селитебный городской низко-высотной спорадической застройки, промышленно-складской городской ландшафт паркостроительного (лесохозяйственного) профиля. При этом категорически отрицается взаимовлияние каких-либо ландшафтных выделов (Barshchevska \& Tyutyunyk, 2014).
Лес урочища «Феофания» в прошлом входил в систему Голосеевского лесного массива, а с 1948 г. его относят к исключительно ценным лесонасаждениям, подлежащим охране. Рекреационная нагрузка на биотопы на разных лесных участках «Феофании» существенно отличается (Shupova, 2014a). В наименее трансформированной части парка-памятника заложен модельный участок № 1 протяженностью 1,2 км. Граничит он с территорией монастыря, дачами, лугами урочища «Феофания» и Палладинскими озерами (рис. 1). Лес - его типичная для региона смешанная дубрава на основе Quercus robur L., Carpinus betulus L., Acer platanoides L., Tilia cordata L., Fraxinus excelsior L. Встречаются отдельные деревья Pinus Syvestris L. Хорошо развит подрост, подлесок и травянистый покров. Трансформация биотопа сводится к наличию протоптанной тропы вдоль участка и паркового ограждения. На границе участка местами встречается мусор, оставленный отдыхающими. Модельный участок № 2 длиной 0,9 км представлен сильнотрансформированным фрагментом леса. Здесь протоптано множество тропинок, нарушивших целостность травянистого яруса и подстилки. Монахами оборудована купель для ритуальных омовений, родники подземных источников собраны в водопровод и оформлены в беседку. Организован отвод воды от них, что привело к тому, что из лесной экосистемы в течение последних 5 лет был нивелирован ручей и связанные с ним микростации. Граничит участок $\mathrm{c}$ разрастающимися кварталами жилой многоэтажной застройки, индивидуальной котеджной застройки, территорией монастыря, садово-парковым и промышленно-складскими паркостроительными ландшафтными выделами ППСПИ «Феофания». Участок активно посещается монахами,

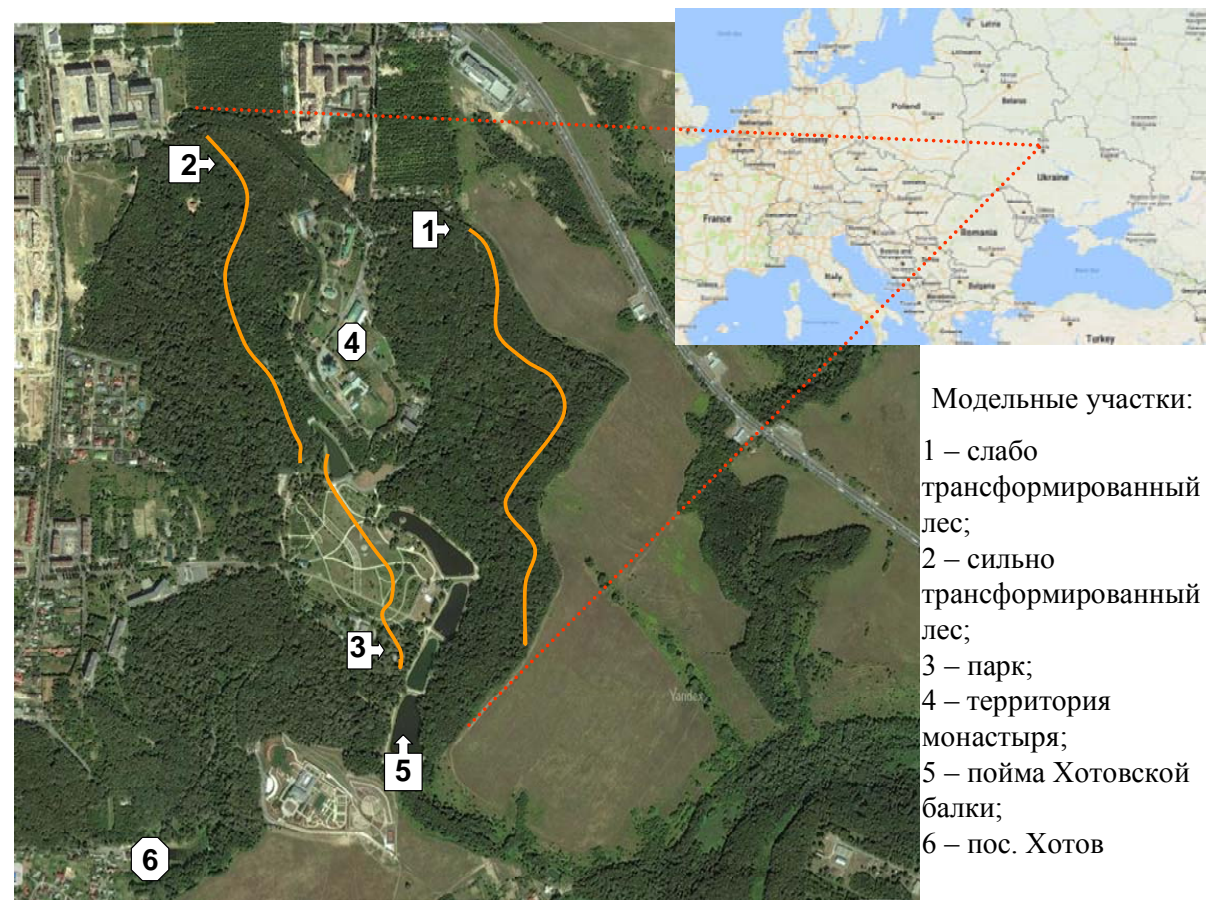

Рис 1. Схема района исследования

верующими, жителями соседних микрорайонов. Модельный участок № 3 протяженностью 0,7 км проложен в садово-парковом городском ландшафтном выделе. Для него характерна наиболее существенная трансформация природного биотопа. Лесная экосистема уничтожена полностью, остались отдельные особи вековых дубов, сосен и ивы, вошедшие в биотопы системы парка. Участок насыщен посадками культурных растений, в том числе чужеродных, разнообразными постройками, дорожками с искусственным покрытием и активно посещается отдыхающими людьми. Здесь часто организовывают культурно-массовые мероприятия.

Материал собирали в гнездовой период (апрель июнь) 2012-2017 гг., для анализа использовали средние за период исследования данные. Численность и распределение птиц определяли методом учетов на маршрутах (Novikov, 1953). Длина заложенных учетных линий составила $0,7-1,2$ км и ограничена протяженностью однородного лесного фрагмента. Анализ ландшафтногенетических фаунистических комплексов авифауны произведен в соответствии с методикой V. P. Belik (2000). 
Сравнивали долю экологических групп в сообществах гнездящихся птиц, в зависимости от предпочитаемых ими биотопов обитания (Belik, 2006) и от выбора микростаций для устройства гнезда (Shirihai et al., 2001; Zavjalov et al., 2005; Camprodon \& Brotons, 2006). Оценивали число видов, подлежащих охране согласно спискам различных международных конвенций и регионально (Konishchuk et al., 2012) охраняемых видов. Индекс синантропизации сообществ гнездящихся птиц определяли по Jedryczkowski (Klausnitzer, 1990). Для средней плотности птиц рассчитывали стандартное отклонение. Сравнивали относительное обилие экологических групп птиц, значимых для оценки сообщества. Вычисляли ряд общепринятых индексов $\dot{\alpha}$-разнообразия сообществ, выражающих зависимости между числом видов и их плотностью, $\beta$-разнообразие оценивали с помощью коэффициентов Жаккара $\left(\mathrm{C}_{\text {Jacquard }}\right)$ и Серенсена $\left(\mathrm{C}_{\text {Sorenson }}\right)$, формулы которых представлены в работе Е. Magurran (1992).

\section{Результаты}

Фауногенетическая структура. На модельных участках парка-памятника садово-паркового искусства «Феофания» отмечено 71 вид птиц 11 отрядов. Из них 63 вида гнездится. Остальные используют модельные биотопы для кормления или отдыха. По градиенту антропической трансформации биотопов выявлено снижение средней плотности гнездования птиц сообществ: $2,91 \pm 0,66 \rightarrow 2,54 \pm 0,67 \rightarrow 2,10 \pm 0,48 \quad$ пар/км маршрутной линии. Количество гнездящихся видов сообщества при этом меняется следующим образом: $48 \rightarrow 51 \rightarrow 39$. Орнитофауна парка-памятника распределена на 9 ландшафтно-генетических фаунистических комплексов, из которых на каждом модельном участке представлено по 8 (рис. 2). Везде доминируют птицы европейского неморального комплекса. Древненеморальные и европейские лесостепные виды занимают второе по долевому участию место. На слаботрансформированном участке леса древненеморальные виды более обильны, чем европейские лесостепные, на сильнотрансформированном участке леса их обилие уравновешивается, а на парковом участке доля европейских лесостепных видов вдвое выше доли древненеморальных. Наиболее малочисленны и представлены не на всех модельных участках птицы лиманного, субсредиземноморского и тропического комплексов. Низкая доля во всех сообществах древнелесостепных птиц: на слаботрансформированном модельном участке 2 вида, на сильнотрансформированных по 1. По градиенту трансформации в сообществах птиц снижается обилие интразональных видов: бореальных в 4 раза, лиманные полностью элиминируют.

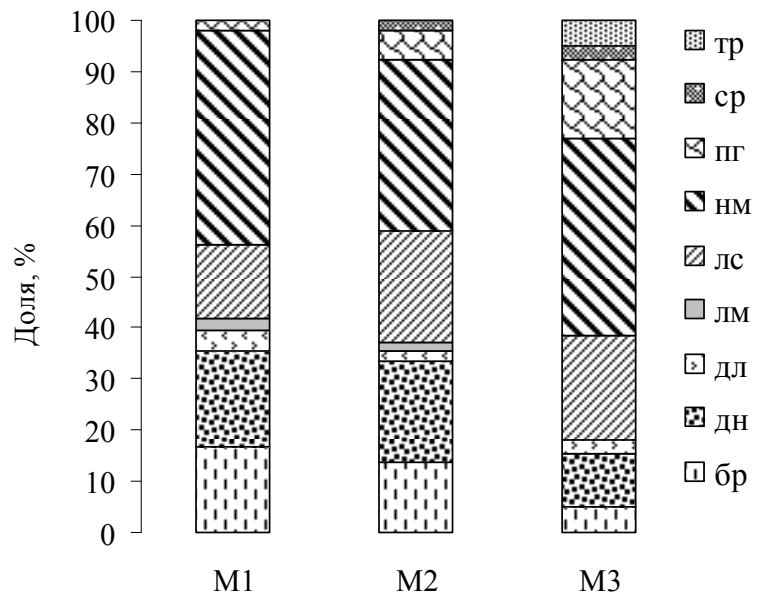

Модельные участки

Рис. 2. Ландшафтно-генетическая структура сообществ (\%): бр - бореальные, дн - древненеморальные,

дл - древнелесостепные, тр - тропические, лм - лиманные, лс - европейские лесостепные, пг - пустынно-горные, ср - субсредиземноморские, нм - европейские неморальные виды

В сообществах гнездящихся птиц по градиенту трансформации модельных участков в списке доминирующих по численности видов наблюдается вытеснение типичных для региона дендрофилов европейского неморального комплекса и преобладание синантропных склерофилов, представителей пустынногорного комплекса (табл. 1).

\section{Таблица 1}

Виды, доминирующие в сообществах гнездящихся птиц

\begin{tabular}{|c|c|c|c|c|}
\hline $\begin{array}{c}\text { Модельный } \\
\text { участок }\end{array}$ & Вид & $\begin{array}{c}\text { Численность, } \\
\text { пар/км } \\
\end{array}$ & $\begin{array}{c}\text { Относительное } \\
\text { обилие, бал }\end{array}$ & Фаунистический комплекс \\
\hline \multirow{5}{*}{ M1 } & Fringilla coelebs L. & 20,9 & 0,149 & Европейский неморальный \\
\hline & Parus major $\mathrm{L}$. & 18,8 & 0,134 & Европейский неморальный \\
\hline & Sitta europaea L. & 12,9 & 0,092 & Европейский неморальный \\
\hline & Turdus merula $\mathrm{L}$. & 11,4 & 0,081 & Европейский неморальный \\
\hline & Erithacus rubecula L. & 10,8 & 0,077 & Европейский неморальный \\
\hline \multirow{5}{*}{ M2 } & Parus major L. & 29,4 & 0,233 & Европейский неморальный \\
\hline & Fringilla coelebs L. & 13,6 & 0,107 & Европейский неморальный \\
\hline & Erithacus rubecula L. & 12,0 & 0,095 & Европейский неморальный \\
\hline & Turdus merula L. & 8,4 & 0,067 & Европейский неморальный \\
\hline & Sturnus vulgaris L. & 7,6 & 0,060 & Пустынно-горный \\
\hline \multirow{6}{*}{ M3 } & Passer montanus L. & 17,4 & 0,209 & Пустынно-горный \\
\hline & Sturnus vulgaris L. & 6,4 & 0,077 & Пустынно-горный \\
\hline & Columba livia Gmelin & 5,7 & 0,068 & Пустынно-горный \\
\hline & Corvus cornix L. & 4,3 & 0,052 & Европейский лесостепной \\
\hline & Parus major L. & 4,2 & 0,050 & Европейский неморальный \\
\hline & Chloris chloris L. & 4,2 & 0,050 & Европейский лесостепной \\
\hline
\end{tabular}

Экологическая структура. Во всех сообществах птиц на гнездовании преобладают дендрофилы. На лесных участках субдоминируют лимнофилы, на парковом склерофилы. Доля этих групп в сообществах птиц лесных участков очень низкая (рис. 3). На лесных модельных участках гнездится только 1 склерофил - обыкновенный скворец (Sturnus vulgaris L.), а на парковом модельном участке только 1 лимнофил - белая трясогузка (Motacilla alba L.). 


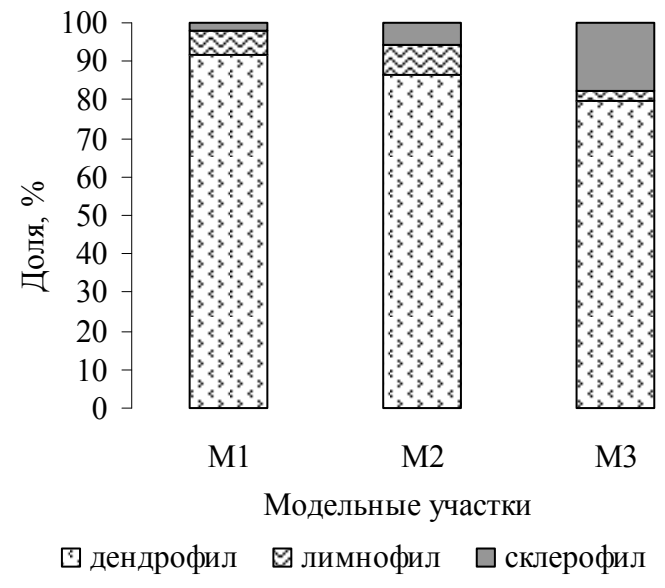

Рис. 3. Распределение птиц сообществ по экологическим группам

Большая часть дендрофилов в основном обустраивает гнезда в кронах растений или селится в дуплах. Доля видов сообщества, гнездящихся в кронах, наибольшая на всех модельных участках, но число видов снижается по градиенту трансформации: $\quad 21 \rightarrow 20 \rightarrow 18$. На земле гнездится 6 видов, доля которых в сообществах по градиенту М1-М2 снижается с 12,5 до $11,8 \%$. На парковом участке эта экологическая гильдия элиминирует. Среди птиц, приспособленных к использованию нескольких типов гнездовых стаций, отмечено 2 вида дендрофилов и 2 вида лимнофилов, которые могут обустраивать гнезда как на земле, так и на деревьях. Из них только зарянка (Erithacus rubecula L.) адаптировалась к обитанию на парковом модельном участке (рис. 4), где она для обустройства гнезд использует полости в столбах освещения парка. С появлением на модельных участках каменных построек в сообщества гнездящихся птиц проникают виды, приспособившиеся к гнездованию в нишах строений. Все они синантропизировавшиеся склерофилы. На территории ППСПИ «Феофания» эту гильдию представляет 5 аборигенных видов (Falco tinnunculus L., Columba livia Gmelin, Hirundo rustica L., Delichon urbica L., Passer montanus L.) и 1 адвентивный горихвостка-чернушка (Phoenicurus ochruros, S.G. Gmelin), отмеченный нами как на сильнотрансформированном лесном участке, так и на парковом.

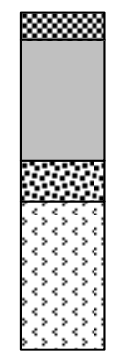

M1

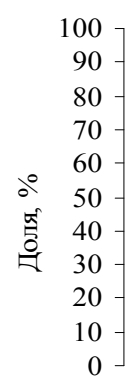

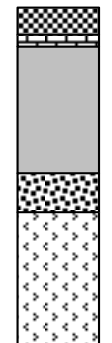

M2

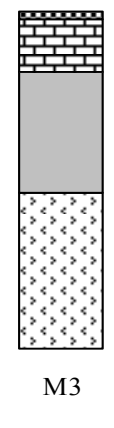

国 На земле

$\begin{array}{ll}\bigotimes \text { В кроне растений } & \text { 国 На земле } \\ \square \text { В дуплах } & \text { В стоениях } \\ \text { Весколько стаций } & \end{array}$

Рис. 4. Распределение видового состава сообществ по типу используемых гнездовых стаций

Дополняет список чужеродных видов на обоих этих модельных участках сирийский дятел (Dendrocopos syriacus, Hemprich et Ehrenberg), а на парковом участке кольчатая горлица (Streptopelia decaocto, Frivaldszky) и канареечный вьюрок (Serinus serinus, Pallas).
Следует отметить, что на территории модельного участка, проложенного через парковую зону, несмотря на полное уничтожение коренного природного биотопа и замену аборигенных видов дятлов, обеспечивающих вторичных дуплогнездников гнездовыми стациями одним видом - сирийским дятлом, это не привело к существенному уменьшению видового состава и обилия вторичных дуплогнездников (рис. 5).

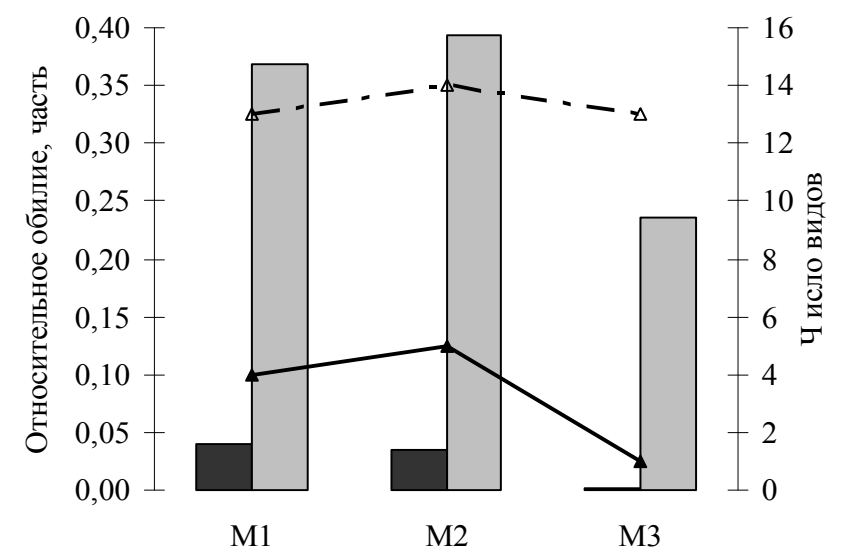

Модельные участки

Обилие первичных дуплогнездников Обилие вторичных дуплогнездников

$\longrightarrow$ Число видов первичных дуплогнездников

- - - Число видов вторичных дуплогнездников

Рис. 5. Соотношение первичных и вторичных дуплогнездников в сообществах гнездящихся птиц

По градиенту трансформации усиливается синантропизация сообществ гнездящихся птиц. При этом абсолютное число синантропных видов (гемисинантропов и облигатных синантропов в сумме) увеличивается постепенно: 30-33-36; число видов облигатных синантропов более резко: 0-2-7. Индекс синантропизации сообществ на градиенте M1-М3 увеличивается в 1,5 раза (рис. 6). Следует отметить в качестве негативного результата воздействия на лесную экосистему тот факт, что относительное обилие синантропных птиц в сообществах увеличивается практически вдвое уже на стадии сильнотрансформированного, но еще лесного участка, в сравнении с которым относительное обилие синантропных птиц сообщества парка увеличивается несущественно. Увеличение синантропности сообществ птиц на лесных участках происходит за счет увеличения численности некоторых гемисинантропов (Columba

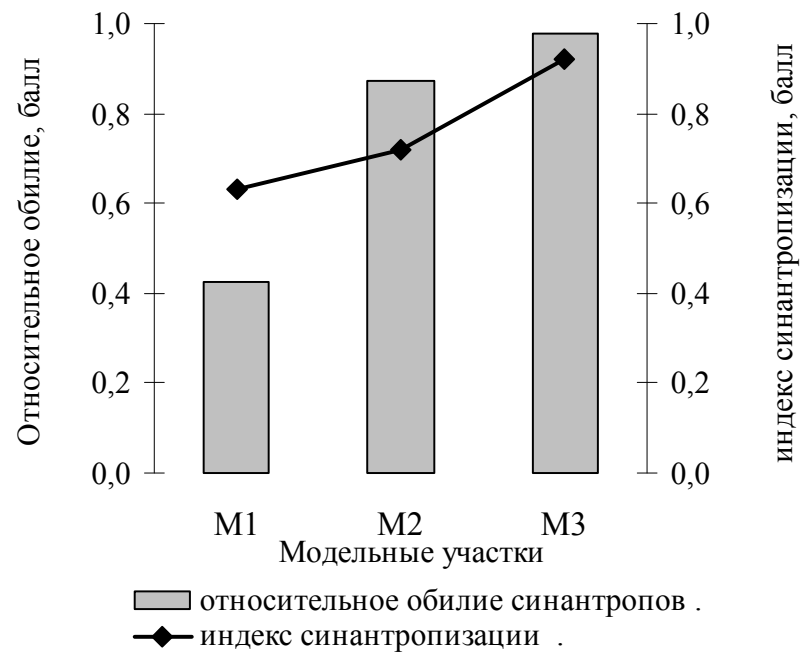

Рис. 6. Синантропизация сообществ гнездящихся птиц 
palumbus L., Dendrocopos major L., Dendrocopos minor L., Pica pica L., Corvus cornix L., Turdus pilaris L., Turdus philomelos C.L. Brehm, Parus major L.), внедрения облигатных синантропов (Dendrocopos syriacus Hemprich et Ehrenberg и Phoenicurus ochruros S.G. Gmelin) и снижения численности (Accipiter nisus L., Tringa ochropus L., Picus canus Gmelin, Dryocopus martius L., Anthus trivialis L., Lanius minor Gmelin, Phylloscopus sibilatrix Bechstein, Ficedula parva Bechstein, Parus palustris L., Sitta europaea L., Coccothraustes coccothraustes L.) или элиминации из сообщества (Buteo buteo L., Hippolais icterina Vieillot) не синантропизировавшихся птиц.

При переходе к парковой экосистеме усиление синантропизации сообществ птиц является следствием увеличения численности тех гемисинантропов, которые более приспособлены к соседству человека (Columba palumbus L., Jynx torquilla L., Motacilla alba L., Garrulus glandarius L., Corvus cornix L., Ficedula albicollis Temminck, Passer montanus L., Acanthis cannabina L.), и ee снижения у менее приспособленных видов, увеличения числа облигатных синантропов за счет Columba livia Gmelin, Streptopelia decaocto Frivaldszky, Hirundo rustica L., Delichon urbica L., Serinus serinus Pallas.

Разнообразие сообществ. Из 5 наиболее широко применяемых для анализа видового разнообразия индексов только индекс Макинтоша демонстрирует существенное (почти двукратное) снижение показателей для сообщества птиц паркового модельного участка. Остальные индексы показывают практически равноценное разнообразие всех сообществ (рис. 7).
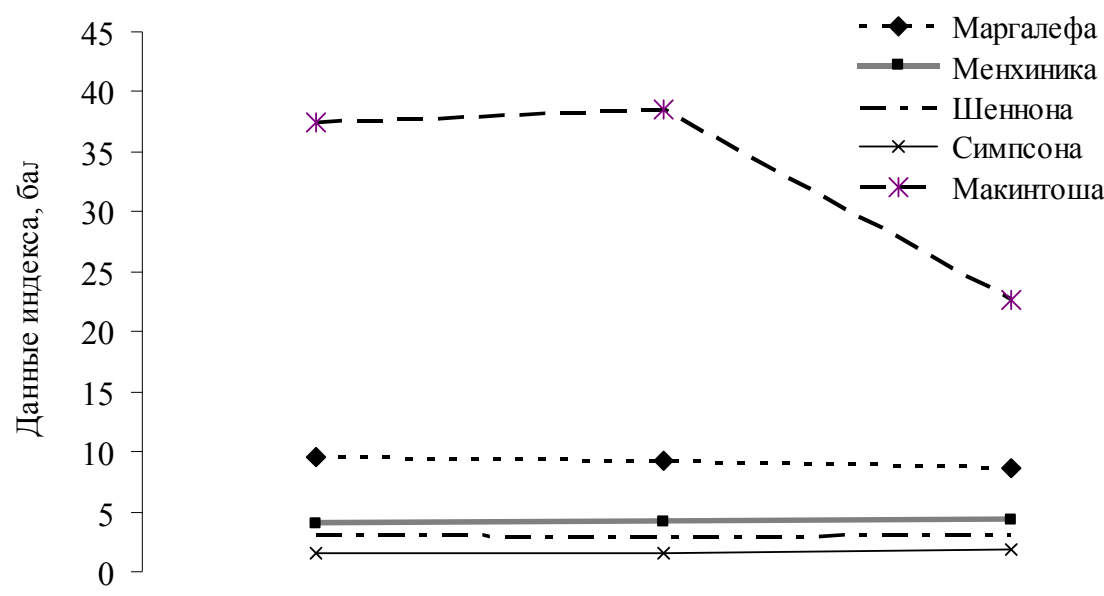

M1

M2

M3

Модельные участки

Рис. 7. Разнообразие сообществ гнездящихся птиц

В отношении проявления степени давления видов, доминирующих по численности, 2 индекса (БергераПаркера и Макинтоша) из 3 проявляют увеличение своих показателей и только данные индекса Симпсона снижаются при переходе от сообществ лесных участков к сообществу паркового (рис. 8).

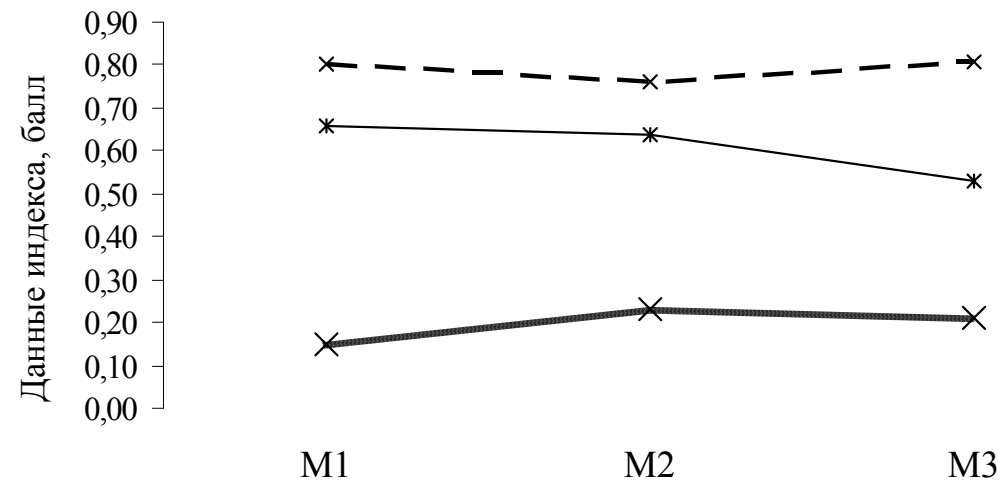

Модельные участки

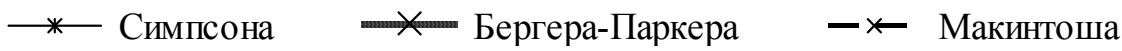

Рис. 8. Проявление доминирования в сообществах гнездящихся птиц

Из индексов распределения видов в сообществе по плотности индекс Пиелу демонстрирует немного большую равномерность сообщества птиц паркового модельного участка, чем лесных, по данным индекса Макинтоша, равномерность распределения видов в сообществах равноценна (рис. 9).
Ранжированные кривые распределения относительного обилия видов в сообществах птиц указывают на резкие изменения баланса доминирования-разнообразия в сообществах при внесении трансформации в лесную экосистему (рис. 10), то есть подтверждают данные индекса Бергера-Паркера. Несмотря на то, что тип леса на 


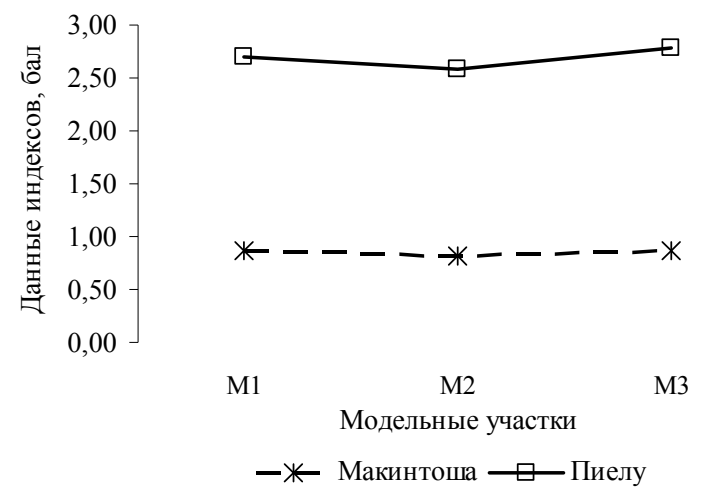

Рис. 9. Распределение видов сообществ гнездящихся птиц по плотности участках М1 и М2 один и тот же (смешанная дубрава с хорошо развитыми нижними ярусами), лишь мозаично затронутый трансформацией, мы наблюдаем резкое перераспределение массива графиков из горизонтального направления в вертикальное при переходе к сообществам трансформированных модельных участков. Их графики указывают на высокий пресс в сообществе 1 доминирующего вида, обилие которого в 2,2-2,7 раза превышает обилие второго по численности вида сообщества. Для слаботрансформированного модельного участка это превышение составляет 1,1 раза.

Данные $\beta$-разнообразия сообществ гнездящихся птиц модельных участков на градиенте M1-M3 почти вдвое ниже, чем при сравнении соседних на линии градиента сообществ. Данные коэффициента Жаккара демонстрируют большую амплитуду значений, нежели Серенсена (табл. 2).

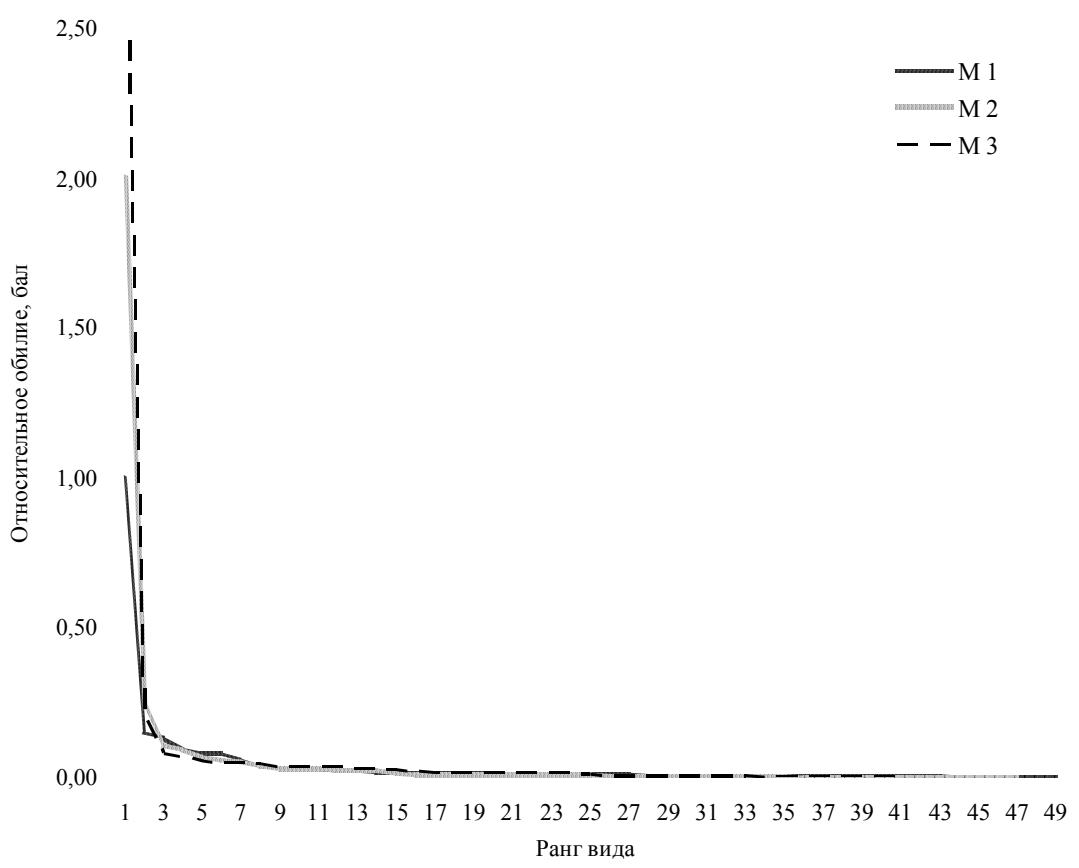

Рис. 10. Распределение видов птиц в сообществе по долевому обилию

Таблица 2

$\beta$-разнообразие сообществ гнездящихся птиц модельных участков

\begin{tabular}{cccc}
\hline Модельный участок & \multicolumn{2}{c}{ Коэффициент } & \multirow{2}{*}{ Число общих видов сообществ } \\
\hline M1-M2 & $\mathrm{C}_{\text {Jacquard }}$ & $\mathrm{C}_{\text {Sorenson }}$ & 41 \\
M2-M3 & 0,71 & 0,83 & 30 \\
M1-M3 & 0,49 & 0,66 & 22 \\
\hline
\end{tabular}

\section{Обсуждение}

В поддержании стабильности функционирования биосферы существенную роль играют леса, которые благодаря сложности своей структурно-функциональной организации чутко реагируют на смену экологических режимов (Rabotnov, 1992; Lavrov et al., 2016 a; Blinkova \& Ivanenko 2018). В селитебной зоне парки лесного типа являются ядрами среды обитания животных, условия которых приближены к природным. Они предоставляют стации, необходимые многим видам для размножения и кормодобывания. В городских парках не все виды имеют возможность безопасного существования (Shupova, 2014 b). Парки ландшафтного типа, в составе которых сохранились участки естественных биотопов и антропическое воздействие в которых меньше, благоприятны для большого числа аборигенных видов животных. Рекреационная нагрузка со стороны отдыхающих людей - одна из главных причин, приводящих к трансформации лесной или лесопарковой экосистемы, что проявляется в уничтожении подстилки, уплотнении поверхностного слоя почвы, механическом повреждении растительности (Lavrov et al., 2016 в). Совокупность повреждений приводит к трансформации растительного сообщества и обусловливает структурно-функциональные изменения сообществ животных. В Европе исследования орнитофауны оцениваются в качестве основополагающих при разработке природоохранных мероприятий. На основе исследований по региональной изменчивости численности и распределения видов в сообществах птиц делаются выводы о связях определенных видов с типами лесов (Graham at al., 2014; Camprodon and Brotons, 2006). Однако исследованию изменчивости сообществ птиц локального пространства посвящено недостаточно работ (Barbe et al., 2018). Вариации характеристик лесной экосистемы, сформированные под действием рекреационной нагрузки, 
дают возможность выявить связи между фитоценотическими параметрами, видовым разнообразием и плотностью населения птиц (Chaplygina et al., 2016; Blinkova \& Shupova, 2017).

Характеристика фауногенетической структуры сообществ птиц показывает степень отличия современной орнитофауны региона от аборигенной фауны коренных природных ландшафтов (Chaplygina et al., 2016; Shupova \& Chaplygina, 2016), дает нам возможность прогнозировать направления дальнейшей эволюции сообществ. В нашем исследовании на всех участках доминируют птицы европейского неморального комплекса. Наличие в сообществах видов субсредиземноморского комплекса связано с заселением региона с середины XX столетия сирийским дятлом (Dendrocopos syriacus Hemprich et Ehrenberg), отмеченным на трансформированных участках. Тропический комплекс представлен как аборигенными видами: кукушкой обыкновенной (Cuculus canorus L.) и пустельгой обыкновенной (Falco tinnunculus L.), так и адвентивным - горлицей кольчатой (Streptopelia decaocto Frivaldszky). Внедрение чужеродных видов птиц - также важный фактор индикации нарушений природной экосистемы, хотя в Украине они не являются опасными трансформерами среды обитания. Обилие чужеродных видов птиц Мельбурна, как и Киева, очень низко в городских остатках лесов по сравнению с городскими фрагментами растительности (White et al., 2009; Shupova, 2017 b). В «Феофании» на участке слаботрансформированного леса чужеродные виды отсутствуют, заселяя расположенный рядом парковый участок.

Из комплекса древнелесостепных птиц на всех модельных участках обитает сорока (Pica pica L.), а в сообществе птиц слаботрансформированного участка леса эту группу дополняет канюк обыкновенный (Buteo buteo L.). Здесь мы ежегодно отмечали территориальное поведение пары птиц, их ритуалы ухаживания, но гнезда не обнаружили. О том, что канюки держатся на участке в течение гнездового сезона, но не приступают к размножению, указывает V. I. Strigunov (2012). А. B. Kostin (2012) описывает имитацию птицами гнездового поведения в неблагоприятные годы. Возможно, что в силу гнездового консерватизма, свойственного виду, канюки ежегодно возвращаются на гнездовой участок, и поскольку ранней весной парк, и тем более его лесные участки, люди практически не посещают, птицы остаются здесь и начинают поиск места для гнездования. С наступлением теплого сезона парк активно используется отдыхающими, что создает существенное давление фактора беспокойства и делает условия гнездования неблагоприятными. В 80-е гг. $\mathrm{XX}$ ст. для лесостепной зоны описано гнездование обыкновенного канюка на расстоянии 400-2600 м (в среднем 1700) от населенного пункта (Strigunov, 2012). P. Szymanski (2010) для запада Польши называет максимально близкое расположение гнезда канюка обыкновенного к зданиям деревни Домбче в 350 м. Паркпамятник «Феофания» расположен сейчас на окраине, но в пределах городской черты Киева. P. Sunde, at al. (2009) указывают, что 40 \% канюков покидают гнездовые участки при приближении человека на 200 м, 60 \% - 100 м, 86 \% 50 м. Ширина слабо трансформированного фрагмента леса «Феофании» составляет на различных его участках 200500 м, что при активизации отдыхающих в лесу людей является некомфортными условиями для птиц. Возможно, что при дальнейшем усилении нагрузки на лесную экосистему со стороны фактора беспокойства птицы покинут территорию парка. Вытеснение древних видов является негативной тенденцией изменения фауногенетической структуры сообществ птиц.

Типы фауны сами по себе позволяют анализировать преимущественно лишь авифауну крупных регионов (Belik, 2006). В связи с этим необходимо исследовать структуру сообществ комплексно, рассматривая максимальное число показателей, демонстрирующих реакцию птиц на воздействие человека на среду их обитания (Chaplygina et al., 2016; Shupova \& Chaplygina, 2016; Blinkova \& Shupova, 2017). Так, под воздействием трансформации среды обитания происходит изменение экологической структуры сообщества гнездящихся птиц: дендрофилы и лимнофилы уступают свою долю в сообществе склерофилам, на гнездование проникают адвентивные виды. Перераспределение происходит в пользу птиц, способных устраивать гнезда закрыто, в полостях построек человека, за счет видов, гнездящихся открыто в кронах растений и на земле. Это является и следствием пластичности поведения некоторых видов (Chaplygina, 2015). Мы хотели бы обратить особое внимание на приспособительные возможности белой трясогузки (Motacilla alba L.), которая сейчас является гемисинантропом и повсеместно гнездится в постройках урбанизированного ландшафта (Chaplygina, 2014). Нами отмечено гнездование белой трясогузки не только в парковых биотопах, но, в том числе, и в строениях кварталов многоэтажной жилой застройки центра Киева. Еще один эвритопный в отношении гнездостроительного стереотипа вид - зарянка, которая в трансформированных лесах достигает такой же плотности, как и в природных (McD. Sweeney et al., 2010). Нет существенных отличий в плотности гнездования зяблика (Fringilla coelebs L.), лазоревки (Parus caeruleus L.), большой синицы (Parus major L.), московки (Parus ater L.) при обитании в лесах урбанизированных территорий Европы (Graham at al., 2014). Все названные виды приспособились к гнездованию не только в трансформированных лесных биотопах, но и в парках Киева.

В то же время перераспределение птиц сообществ по использованию гнездовых стаций связано и с элиминацией видов, не приспособившихся к темпам изменения биотопа (Shupova, 2017a), или существенным снижением численности. Черный дрозд (Turdus merula L.) в Европе считается наиболее гибким видом (Shirihai et al., 2001), хотя в разреженных лесах он менее обилен, чем в густых (Camprodon \& Brotons, 2006). На исследуемых нами модельных участках его численность изменялась следующим образом: 11,4-8,4-2,8 пар/км. На лесных участках он является доминирующим по численности видом, а на парковом - фоновым. В Киеве обитает оседлая синантропная субпопуляция черного дрозда. Мы считаем, что лесные участки заселяют оседлые особи синантропной и перелетные несинантропной субпопуляций. На сильнотрансформированных территориях представители несинантропной субпопуляции не гнездятся, в связи с чем мы наблюдаем такую разницу в плотности вида. Описано, что в Каталонии вяхирь (Columba palumbus L.), сойка (Garrulus glandarius L.) и зяблик не используют леса с пониженным кустарниковым покровом (Camprodon \& Brotons, 2006). В Киеве в последнее десятилетие проходит активная синантропизация вяхиря (Shupova, 2014 с; Shupova, 2015), и его численность проявляет увеличение по градиенту трансформации: 1,2-1,6-2,2 пар/км.

Малочисленность дятлов считается причиной недостаточного количества дупел и, как следствие, приводит к снижению обилия видов, которые гнездятся в дуплах деревьев (Robles at al., 2011; Felton at al., 2016). Наши исследования показывают, что в парковых экосистемах уменьшение количества дятлов не влечет за собой существенного уменьшения видового состава и обилия вторичных дуплогнездников, поскольку представители синантропных субпопуляций используют для гнездования полости в постройках по благоустройству парка.

Изменение видового состава лесных деревьев может влиять на выбор птицами мест обитания (Gabbe et al., 2002), структуру сообщества и на разнообразие (Tews at al, 2004; Gil-Tena at al, 2007; Moreno Rueda \& Pizzaro, 2009; 
Šalek at al, 2010) сообществ. Для поддержания разнообразия птиц важно наличие кустарникового яруса, коряг, упавших на почву, и пней (Assadi et al, 2015). Гетерогенность среды способствует увеличению á-разнообразия (Katsimanis et al, 2006). Птицы играют важную функциональную роль в лесах и других природных экосистемах и обычно считаются хорошими индикаторами биоразнообразия (Sergio et al., 2006; Şekercioğlu, Ç.H., 2006; Gil-Tena et al.,2007). Поэтому карты богатства видов птиц могут использоваться как экономически эффективный метод оценки биоразнообразия в определенном географическом регионе (Ozdemir at al., 2017). Богатство большинства групп птиц не имело существенной зависимости от качества наземной растительности и кустарникового слоя, величины фрагмента леса радиусом более 500 м и помимо остаточного размера фрагмента леса единственным аспектом, который повышает видовое богатство, является наличие в остатке прибрежной растительности (White et al., 2009). В исследуемом лесопарке наличие озер не повлияло на увеличение $\alpha$-разнообразия сообществ гнездящихся птиц на маршруте М3 в связи с чрезмерной рекреационной нагрузкой со стороны отдыхающих. Водноболотные птицы здесь лишь кормятся, а гнездиться улетают в другие биотопы урочища. Зато слаботрансформированный участок характеризуется немного большим видовым разнообразием в том числе и в связи с наличием полян, привлекательных для опушечных видов птиц: козодоя (Caprimulgus europaeus), жулана (Lanius collurio), лесного конька (Anthus trivialis L.). В нашем исследовании большинство наиболее активно применяемых для анализа о́-разнообразия индексов, основывающихся на соотношении плотности видов, показывает равноценное качество всех сообществ. Анализ распределения видов по долевому обилию демонстрирует большие различия, следовательно, ранжированные кривые относительного обилия видов являются более чутким показателем трансформации сообщества, чем данные индексов доминирования и равномерности распределения видов в сообществе. Оценка связи между индексами á-разнообразия сообществ птиц и структурой лесного фитоценоза показала хорошие результаты в качестве индикатора интенсивности рекреационной нагрузки в пределах лесных экосистем (Blinkova \& Shupova, 2017).

\section{Выводы}

На модельных участках парка-памятника садовопаркового искусства «Феофания» отмечен 71 вид птиц, 63 из которых гнездятся, представлено 11 отрядов орнитофауны. Количество гнездящихся видов сообществ модельных участков не зависит от градиента антропической трансформации, а средняя численность гнездящихся птиц снижается: $2,91 \pm 0,66 \rightarrow 2,54 \pm 0,67 \rightarrow 2,10 \pm 0,48$ пар/км. По градиенту трансформации условий обитания установлено изменение ландшафтно-генетической структуры сообществ птиц в направлении увеличения доли видов европейского неморального, европейского лесостепного, пустынногорного и тропического фаунистических комплексов за счет вытеснения бореальных и древних видов. В списке доминирующих по численности птиц происходит замена дендрофилов, представителей европейского неморального комплекса синантропными склерофилами пустынногорного комплекса. По градиенту трансформации уменьшается число видов птиц, гнездящихся открыто в кронах растений с 21 до 18, видов, приспособленных к использованию нескольких типов гнездовых стаций - с 4 до 1, видов, обустраивающих гнезда на земле - с 6 до 0. Число видов птиц, гнездящихся в нишах строений, возрастает с 0 до 6 , а число чужеродных видов - с 0 до 4 . В парковых экосистемах уменьшение видового состава дятлов не влечет за собой существенного уменьшения видового состава и относительного обилия вторичных дуплогнездников, поскольку представители синантропных субпопуляций используют для гнездования полости в постройках по благоустройству парка. Большинство наиболее активно применяемых для анализа $\alpha$-разнообразия индексов показывает равноценное качество всех сообществ. Сравнительный анализ распределения видов по плотности и по долевому обилию указывает на то, что ранжированные кривые относительного обилия видов являются более чутким показателем трансформации сообщества, чем данные индексов доминирования и равномерности распределения видов в сообществе. Данные $\beta$-разнообразия гнездящихся птиц при трансформации лесной экосистемы в парковую снижаются вдвое. Внедрение в лесную экосистему даже небольшого количества строений приводит к увеличению относительного обилия синантропных птиц вдвое в сравнении с сообществом слаботрансформированного леса. По градиенту трансформации участков абсолютное число гнездящихся синантропных видов птиц увеличивается постепенно: 30-33-36; облигатных синантропов более резко: $0-2-7$; индекс синантропизации сообществ повышается в 1,5 раза: $0,63-0,72-0,92$.

\section{References}

Assadi, S. B., Kaboli, M., Etemad, V., Khanaposhtani, M. G., \& Tohidifar, M. (2015). Habitat selection of cavity-nesting birds in the Hyrcanian deciduous forests of northern Iran. Ecological Research, 30(5), 889-897. DOI: 10.1007/s11284-015-1293-z.

Barbe, L., Morel, R., Rantier, Y., Lebas, J-F., \& Butet, A. (2018). Bird communities of a temperate forest: spatio-temporal partitioning between resident and migratory species. Journal of Ornithology, 159(2), 457-469. DOI: 10.1007/s10336-0171523-y.

Barshchevska, N. \& Tyutyunyk, Y. (2014). Ландшафтне різноманіття території паркових зон м. Києва (на прикладі парку-пам'ятки садово-паркового мистецтва «Феофанія» [Landscape diversities of the territory of garden zones in Kyiv (the example of garden-relic of landscape art «Feofaniya»)]. Physical geography and geomorphology, 3(75), 70-74 (in Ukrainian).

Belik, V. P. (2000). Pticy stepnogo Pridon'ja: formirovanie fauny ee antropogennaja transformacija i voprosy ohrany [Birds steppe Pridonya: the formation of the fauna and its anthropogenic transformation and conservation]. Iz-vo RGPU, Rostov/n.D (in Russian).

Belik, V. P. (2006). Faunogenetic Structure of the Palearctic Avifauna. Entomological Review, 86(1), S15-S31. DOI: 10.1134/S0013873806100022.

Blinkova, O., \& Shupova, T. (2017). Bird communities and vegetation composition in the urban forest ecosystem: correlations and comparisons of diversity indices. Ekológia (Bratislava), 36(4), 366-387. DOI: 10.1515/eko-2017-0029.

Blinkova, O., \& Ivanenko O. (2018). Communities of woody vegetation and wood destroying fungi in natural and seminatural forests of Kyiv city, Ukraine. Central European Forestry Journal, 64, 55-66. DOI: 10.1515/forj-2017-0030.

Bulakhov, V. L., Gubkin, A. A., Ponomarenko, O. L., \& Pakhomov, O. Y. (2008). Biologichne riznomanittya Ukrainy. Dnipropetrovska oblast'. Ptahy: Negorobcepodibni (Aves: Non-Passeriformes) [Biological diversity of Ukraine. Dnipropetrovsk region. Aves: Non-Passeriformes]. Dnipropetrovsk University Press, Dnipropetrovsk (in Ukrainian).

Bulakhov, V. L., Gubkin, A. A., Ponomarenko, O. L., \& Pakhomov, O. Y. (2015). Biologichne riznomanittya Ukrainy. Dnipropetrovska oblast'. Ptahy: Gorobcepodibni (Aves: Passeriformes) [Biological diversity of Ukraine. Dnipropetrovsk region. Aves: Passeriformes]. Dnipropetrovsk University Press, Dnipropetrovsk (in Ukrainian). 
Camprodon, J., \& Brotons, L. (2006). Effects of undergrowth clearing on the bird communities of the Northwestern Mediterranean Coppice Holm oak forests. Forest Ecology and Management, 221(1-3), 72-82. DOI: 10.1016/j.foreco.2005.10.044.

Croci, S., Buter, A., \& Clergeau, Ph. (2008). Does urbanization filter birds on the basis of their biological traits? Condor, 110(2), 223-240. DOI: 10.1525/cond.2008.8409.

Chaplygina, A. B. (2014). Materialy do ekolohii biloi plysky (Motacilla alba) $\mathrm{v}$ antropohennykh landshaftakh pivnichnoho skhodu Ukrainy [Materials to ecology of the White Wagtail Motacilla alba) in anthropogenic landscapes in the North-East of Ukraine]. Berkut, 23(2), 71-79 (in Ukrainian).

Chaplygina, A. B. (2015). Ekoloho-faunistychnyi analiz i uspishnist rozmnozhennia dendrofilnykh ptakhiv na transformovanykh terytoriiakh Pivnichno-Skhidnoi Ukrainy [Ecofaunistic analysis and breeding successful of dendrophilous birds on the transformed territories of NorthEastern Ukraine]. Studia Biologica, 9(2), 133-146 (in Ukrainian).

Chaplygina, A. B., Shupova, T. V., \& Nadtochiy, A. S. (2016). Ornitifauna nacionalnogo prirodnogo parka "Gomolshanskie lesa" [The avifauna of the National Nature Park "Homilshanski Lisy"]. Visnyk of Dnipropetrovsk University. Biology, Ecology, 24 (1), 124-133 (in Russian).

Etterson, M. A., Etterson, J. R., \& Cuthbert, F. J., (2007). A robust new method for analyzing community change and an example using 83 years of avian response to forest succession. Biological Conservation, 138 (1-4), 381-389. DOI: 10.1016/j.biocon.2007.05.003.

Fischer, J., Lindenmayer, D. B., Blomberg, S. P., MontagueDrake, R., Felton, A., \& Stein, J. A. (2007). Functional Richness and Relative Resilience of Bird Communities in Regions with Different Land Use Intensities. Ecosystems, 10 (6), 964-974. DOI: 10.1007/s10021-007-9071-6.

Felton, A., Hedwall, P. O., Lindbladh, M., Nyberg, T., Felton, A. M., Holmström, E., Wallin, I., Löf, M., \& Brunet, J. (2016). The biodiversity contribution of wood plantations: Contrasting the bird communities of Sweden's protected and production oak forests. Forest Ecology and Management, 365 (1), 51-60 DOI: 10.1016/j.foreco.2016.01.030.

Gabbe, A. P, Robinson, S. K., \& Brawn, J. D. (2002). Tree-Species Preferences of Foraging Insectivorous Birds: Implications for Floodplain Forest Restoration. Conservation Biology, 16(2), 462-470. DOI: 10.1046/j.1523-1739.2002.00460.x.

Gardner, T. A., Barlow, J., Araujo, I. S., Ávila-Pires, T. C., Bonaldo, A. B., Costa, J. E., Esposito, M. C., Ferreira, L. V., Hawes, J., Hernandez, M. I., Hoogmoed, M. S., Leite, R. N., Lo-Man-Hung, N. F., Malcolm, J. R., Martins, M. B., Mestre, L. A. M., Miranda-Santos, R., Overal, W. L., Parry, L., Peters, S. L., Ribeiro-Junior, M. A., Da Silva, M. N. F., Da Silva Motta, C., \& Peres, C. A. (2008). The costeffectiveness of biodiversity surveys in tropical forests. Ecology Letters, 11 (2), 139-150. DOI: 10.1111/j.14610248.2007.01133.x.

Gil-Tena, A., Saura, S., \& Brotons, L., (2007). Effects of forest composition and structure on bird species richness in a Mediterranean context: implications for forest ecosystem management. Forest Ecology and Management, 242 (3-4), 470-476. DOI: 10.1016/j.foreco.2007.01.080.

Graham, C. T., Wilson, M. W., Gittings, T., Kelly, T. C., Irwin, S., Sweeney, O. F. McD., \& O'Halloran, J. (2014). Factors affecting the bird diversity of planted and semi-natural oak forests in Ireland. Bird Study, 61, 309-320. DOI: 10.1080/00063657.2014.927415.

Katsimanis, N., Dretakis, D., Akriotis, T., \& Mylonas, M. (2006). Breeding bird assemblages of eastern Mediterranean shrublands: Composition, organisation and patterns of diversity. Journal of Ornithology, 147(3), 419-427. DOI: 10.1007/s10336-005-0024-6.

Kostin, A. B. (2012). Territorial'noe raspredelenie, dinamika chislennosti i jekologija obyknovennogo kanjuka na juge Kaluzhskoj oblasti [Territorial distribution, population dynamics and ecology of the Buzzard in the south of Kaluga Region]. Buzzards of North Eurasia: Distribution, Population Status, Biology. Proceedings of the 6th International Conference on Birds of Prey and Owls of North Eurasia, Kryvyi Rih, 27-30 September 2012. Press, Kryvyi Rih, 61-73 (in Russian).

Klausnitzer, B. (1990). Jekologija gorodskoj fauny [Ecology of urban fauna]. Mir, Moscow (in Russian).

Konishchuk, V., Mosyakin, S., Tsarenko, P., Kondratyuk, S., Borisova, E., Virchenko, V., Prydyuk N., Fitsaylo T., Havrys G., Tytar, V. \& Shupova, T. (2012). Chervona knyha Kyivskoi oblasti [Red book of the Kyiv area]. Agroecological journal, (3), 46-58 (in Ukrainian).

Kurosawa, R. (2009) Disturbance-induced bird diversity in early successional habitats in the humid temperate region of northern Japan. Ecological Research, 24 (3), 687-696. DOI: 10.1007/s11284-008-0539-4.

Lavrov, V. V., Blinkova, O. I., Ivanenko, O. M., \& Polischuk Z. V. (2016). Konsortyvni zviazky aloforoidnykh hrybiv ta Quercus robur L. u mistsiakh promyslovoho dobuvannia hranitu i rekreatsiinoi diialnosti [Consortial relations of aphyllophoroid fungi and Quercus robur L. in places of industrial granite mining and recreational activities]. Studia Biologica, 10(2), 163-174 (in Ukrainian).

Lavrov, V., Blinkova, O., Miroshnik, N., \& Ivanenko O. (2016). Synekolohichni zasady diahnostyky transformatsii strukturnofunktsionalnoi orhanizatsii lisovykh ekosystem $\mathrm{v}$ aspekti evoliutsii [Synecological principles of diagnostics of transformation of structural and functional organization of forest ecosystems in the evolutionary aspect]. Factors in Experimental Evolution Organisms, 18, 186-190 (in Ukrainian).

Magurran, E. (1992). Ekologicheskoe raznoobrazie i ego izmerenie [Ecological diversity and its measurement]. Mir, Moscow (in Russian).

McD. Sweeney, O. F., Wilson, M. V., Irwin, S., Kelly, T. C., \& O'Halloran, J. (2010). Are bird density, species richness and community structure similar between native woodlands and non-native plantations in an area with a generalist bird fauna? Biodiversity and Conservation, 19(8), 2329-2342. DOI: 10.1007/s10531-010-9844-7.

Moreno Rueda, G., \& Pizzaro, M. (2009). Relative influence of habitat heterogeneity, climate, human disturbance, and spatial structure on vertebrate species richness in Spain. Ecological Research, 24(2), 335-344. DOI: 10.1007/s11284-008-0509-x.

Novikov, G. A. (1953). Polevye issledovanija po jekologii nazemnyh pozvonochnyh [Field studies on the ecology of terrestrial vertebrates]. Sovetskaja Nauka, Moscow (in Russian)

Ozdemir, I., Mert, A., Ozkan, U. Y., Aksan, S., \& Unal, Y. (2017). Modelling Bird Species Richness Using Satellite Data. Recent Advances in Environmental Science from the EuroMediterranean and Surrounding Regions. Proceedings of Euro-Mediterranean Conference for Environmental Integration (EMCEI-1), Tunisia 2017. Conference Paper November 2017. DOI: 10.1007/978-3-319-70548-4_503.

Pakhomov, O. Y., Gasso, V. Y., Goloborodko, K. K., Poljakov, M. V., Grycan, Y. I., Bulakhov, V. L., Brygadyrenko, V. V., Kljuchko, Z. F., Mezhzherin, S. V., Novicky, R. O., Pysanec, Y. M., Pljushh, I. G., Ponomarenko, O. L., Puchkov, O. V., \& Radchenko, V. G. (2011). Chervona knyga Dnipropetrovskoi oblasti. Tvarynnyj svit [The red book of Dnipropetrovsk region. Animals]. New Print, Dnipropetrovsk (in Ukrainian).

Palomino, D., \& Carrascal, L. M. (2005). Birds on novel island environments. A case study with the urban avifauna of Tenerife (Canary Islands). Ecological Research, 20 (5), 611-617. DOI: $10.1007 / \mathrm{s} 11284-005-0083-4$.

Rabotnov, T. A. (1992). Fitocenologija [Phytocenology]. Moscow University, Moscow (in Russian).

Romanenko, O. V., Arsan, O. M., Арсан O. M., Kipnis, L. S., \& Sitnic U. M. (2015). Ekolohichni problemy kyivskykh vodoim 
i prylehlykh terytorii [Ecologic problems of Kiev water and adjacent territories]. Nauk. dumka, Kyiv (in Ukrainian).

Robles, H., Ciudad, C., \& Matthysen, E., (2011). Tree-cavity occurrence, cavity occupation and reproductive performance of secondary cavity-nesting birds in oak forests: The role of traditional management practices. Forest Ecology and Management, 261(8), 1428-1435. DOI: 10.1016/j.foreco.2011.01.029.

Šalek, M., Svobodova, J., \& Zasadil, P. (2010). Edge effect of lowtraffic forest roads on bird communities in secondary production forests in central Europe. Landscape Ecology, 25(7), 1113-1124. DOI: 10.1007/s10980-010-9487-9.

Sergio, F, Newton, I., Marchesi, L, \& Pedrini, P. (2006). Ecologically justified charisma: preservation of top predators delivers biodiversity conservation. Journal of Applied Ecology, 43, 1049-1055. DOI: 10.1111/j.1365-2664.2006.01218.x.

Sekercioğlu, C. H. (2006). Increasing awareness of avian ecological function. Trends in Ecology and Evolution, 21 (8), 464-471. DOI: 10.1016/j.tree.2006.05.007.

Shupova, T. V. (2014 a). Ornitologicheskoe raznoobrazie parkapamjatki sadovo-parkovogo iskusstva «Feofanija» [The diversity of avifauna in park, «Feophaniya»] Zapovidna sprava, 20(1), 98-102 (in Russian).

Shupova, T. V. (2014 b). Ornitofauna selitebnoj zony Kieva [Avifauna in settlement zone of Kiev]. The Journal of V. N. Karazin Kharkiv National University, Biology, 21, 83-91 (in Russian).

Shupova, T. V. (2014 c). Utvorennia miskoi populiatsii pryputnia (Columba palumbus L.) v Kyievi [Creation of the urban population of the Columba palumbus L. in Kyiv]. Visnyk of Tarasa Shevchenka Kyiv National University. The problems of regulation of biological functions, 1 (17), 36-39 (in Ukrainian).

Shupova, T. V. (2015). Adaptatsiia ptakhiv riadu holubopodibnykh (Columbiformes) do transformatsii seredovyshcha isnuvannia [Adaptation of the birds the order (Columbiformes) to the transformation of habitat] Visnyk of Tarasa Shevchenka Kyiv National University Biology, 1(69), 46-51 (in Ukrainian).

Shupova, T. V. (2017 a). Transformacija raznoobrazija ornitofauny pod dejstviem rekreacionnoj nagruzki [Transformation in the diversity of avifauna under the influence of recreational load]. Biosystems Diversity, 25(1), 45-51 (in Russian). DOI: $10.15421 / 011707$.

Shupova T. V. (2017 b). Alien species of birds in the parks of Kiev. The V International Symposium Invasion of alien species in Holarctic: book of abstrscts / Ed. Yu. Yu. Dgebuadze [et al.]. Yaroslavl, 166.
Shupova, T. V., \& Chaplygina, A. B. (2016). Ornitifauna zakaznika obschegosudarstvennogo znacheniy "Luchkovsky" [The avifauna of the reserve of national importance "Luchkivskiy"]. The Journal of V. N. Karazin Kharkiv National University, 26, 148-156 (in Russian).

Shirihai, H., Gargallo, G., \& Helbig A. (2001). Sylvia Warblers. In Ch. Helm (Ed.), Identification, taxonomy and phylogeny of the Genus Sylvia. London: Black.

Strigunov V. I. (2012). Sostojanie populjacij obyknovennogo kanjuka i kurgannika v 80-e gg. XX st. v lesostepi Ukrainy [The state of populations of the Common Buzzard and Longlegged Buzzard in the forest-steppe zone of Ukraine during the 1980s ]. Buzzards of North Eurasia: Distribution, Population Status, Biology. Proceedings of the 6th International Conference on Birds of Prey and Owls of North Eurasia, Kryvyi Rih, 27-30 September 2012. Press, Kryvyi Rih, 218-236 (in Russian).

Szymanski, P. (2010). Nesting of Tree Sparrow Passer Montanus in the Nest of Common Buzzard Buteo Buteo. International Studies on Sparrows. The Journal of University of Zielona Gora, 34 (1), 25-26. DOI: 10.1515/isspar-2015-0005.

Sunde, P., Odderskær, P., \& Storgaard, K. (2009). Sunde P., Odderskær, P. \& Storgaard, K. (2009). Flight distances of incubating Common Buzzards Buteo buteo are independent of human disturbance. Ardea, 97(3), 369-372. DOI: 10.5253/078.097.0313

Tews, J., Brose, U., Grimm, V., Tielbörger, K., Wichmann, M. C., Schwager, M. \& Jeltsch, F. (2004). Animal species diversity driven by habitat heterogeneity/diversity: the importance of keystone structures. Journal of Biogeography, 31(1), 79-92. DOI: 10.1046/j.0305-0270.2003.00994.x.

Whelan, C. J., Wenny, D. G., \& Marquis, R. J., 2008. Ecosystem services provided by birds. Annals of the New York Academy of Sciences, 1134, 25-60. DOI: 10.1196/annals.1439.003.

White, John G., Fitzsimons, James A., Palmer, Grant C., \& Antos, Mark J. (2009). Surviving urbanisation : maintaining bird species diversity in urban Melbourne. Victorian naturalist, 126 (3), 73-78.

Zavjalov, E., Shljahtin, G., Tabachishin, V., \& Jakushev N. (2005). Jekologo-faunisticheskaja harakteristika avifauny severa nizhnego Povolzh'ja [Ecological-faunistic characteristic by avifauna of the north of Lower Volga region]. Journal Saratov Univ. Ser. Chem. Biol. Ecol., 2, 49-59 (in Russian). 